Nutr. Dieta 1960;2:I-IV

\title{
Contents, Vol. 2, 1960
}

\section{Nutritio et Dieta}

Europäische Zeitschrift für Ernährung und Diätetik

European Review of Nutrition and Dietetics

Revue européenne de nutrition et de diététique

EDITORES

E. J. BIGWOOD, Bruxelles H.

H. H. BERG, Hamburg

E.

R. BOLLER, Wien J.

E. LE BRETON, Paris F.

L. BRULL, Liège A.

F. S. P. VAN BUCHEM, Groningen H.

M. COPPO, Modena A.

H. D. CREMER, Giessen R.

CH. DARNAUD, Toulouse G.

J. DELFOSSE, Bruxelles H.

M. DEMOLE, Geneve T.

M. J. L. DOLS, Wassenaar G.

G. DUCHESNE, Paris A.

H. GLATZEL, Dortmund H.

W. GLOOR-MEYER, Zurich J.

J. GONTEA, BucarestF.

H. GOUNELLE, Paris

L.

W. HALDEN, Graz G.

C. DEN HARTOG, Den Haag

G.

R. JACQUOT, Paris F.

B. C. P. JAN SEN, Amsterdam

KRAUT, Dortmund

I. KÜHNAU, Hamburg

LEDERER, Louvain

MANCINI, Roma

P. MEIKLEJOHN, Edinburgh

G. MOGENA, Madrid

MOSSE, Paris

NICOLAYSEN, Oslo

PEQUIGNOT, Paris

SARLES, Marseille

F. S. M. VAN SCHAIK, Den Haag

S. SCHETTLER, Stuttgart

VAN DER SCHUEREN, Gand 


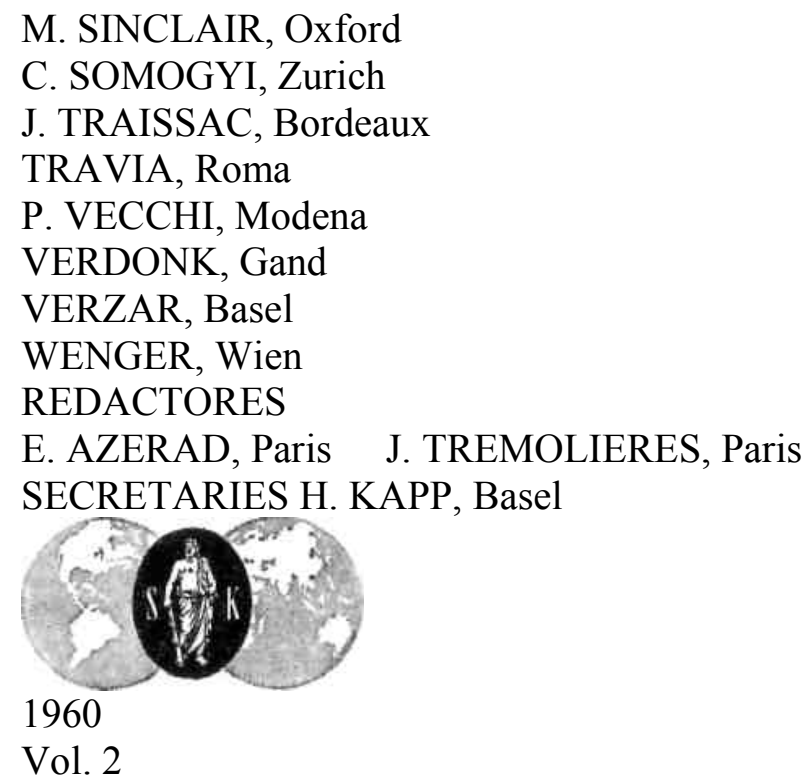

BASEL (Schweiz)

\section{S. KARGER}

NEW YORK

Alle Rechte, insbesondere das der Übersetzung in fremde Sprachen, vorbelialten.

Ohne ausdrücklicbe Genehmigung des Verlages ist es auch nicht gestattet, dieses Buch oder Teile daraus auf photomechanischem Wege (Photokopie, Mikrokopie) zu vervielfältigen.

(C)

Copyright 1960 by S. Karge $\Gamma$ AG, Basel

Printed in Switzerland

Cliches: Aberegg-Sterner \& Cie., AG, Bern und Sterner \& Cie., AG, Basel

Di·uck: Lüdin AG, Liestal

INDEX

Übersichtsreferate - Surveys - Revues gênérales

MaSek, J.: Etude de la cholestérolémie dans différents groupes de population. - Untersuchungen über die Cholesterínaemie in verschíedenen Bevölkerungsgruppen

Stoner, H. B.: The Addition of Chemicals to Food. - Beimengung von Chemïkalien zu Nahrungsmitteln. - L'addition de produits chimiques aux aliments

Oríginalarbeíten - Original Paper - Travaux origínaux

Azérad, E.: Sur une diététique de Гathérosclérose. - Über eíne Díätetík der Atherosklerose. Dietetics in Atherosclerosis 67

Azérad, E.: vide Salamin, L.

Ardaillou, R.: vide Richet, G.

Badetti, J.: vide Sarles, H.

Bartosová, D.: vide Zbuzek, V.

Canzler, H. und Glatzel, H.: Untersuchungen zur quantitativen Bestimmung der Magensalzsäure mit Kationenaustauschern. - Observations on the Quantitative Determination of Gastric Hydrochloric Acid with Cation Exchange Compounds. - Recherches sur le dosage quantitatif de Tacidité gastrique par la méthode des échanges de cations 
Dahl, C.: vide Sarles, H.

Gabbe, R.: vide Jahnke, K.

Ghata, J.: vide Salamin, L.

Glatzel, H.: vide Canzler, H.

Gounelle, H.: Les risques d'intoxications alimentaires dans les collectivités à la lumière de Гexpérience française des 40 dernières années. Role du diététicien. - Das Nahrungstnittelintoxïkationsrisïko beí Gemeínschaftsverpflegungen in Frankreích während der letzten 40 Jahre. Aufgabe des Díätetíkers. - Risks of Alimentary Intoxication in Communities Reviewed in the Light of Experience in France during the Past 40 Years. Role of the Dietician 33 Greusard, C.: vide Sarles, H.

Hudson, A. Z.: Developmental Deviations Produced by General Malnutrition. (Attempts to Produce Experimental Kwashiorkor.) - Entwícklungsstörungen durch ungenügende Ernährung. (Versuche zur experímentellen Erzeugung von Kwashiorkor,). - Anomalies du développement dans les états de malnutrition totale. (Essais de production expérimentale de Kwashiorkor) 53

Jahnke, K. und Gabbe, R.: Bedeutung und Methodik von Ernährungsanamnesen. - Signi ficance and Conduct of Dietary Patient Histories. - Importance et méthodique des enquêtes alimentaires 115

Kallõs, P. und Kallôs-Deffner, L.: Untersuchungen über die Wirkung eines appetitreduzierenden Mittels (Tylinal $\left.{ }^{\circledR}\right)$ an Asthmapatienten mit Übergewicht. - Investigations into the Effect of an Anorexogeníc Compound (Tylinal®) on Asthmatics with Overweight. -

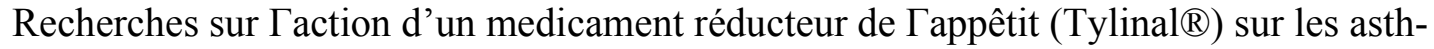
matiques obèses 229

Kallôs-Deffner, L.: vide Kallõs, P.

KojeckÝ, Z. et BenÝSek, L.: Diététique de Thyperlipémie essentielle. - Diätetík der essentíellen Hyperlípämie. - Dietetics of Essential Hyperlipaemia 239

Lewin, J.: vide Salamin, L.

Masek, J.: Etude de la cholestérolémie dans différents groupes de population. - Unter suchungen über die Cholesterinämie in verschiedenen Bevölkerungsgruppen. - A Study of Cholesterolaemia in Different Groups of the Population 193

Richet, G. et Ardaillou, R.: Activité tripeptidasique du plasma et catabolisme azote. Trípeptidasen-Aktívítät des Plasmas und Stickstoffkatabolismus. - Plasma Tripeptidase Activity and Nitrogen Catabolism 91

Salamin, L.; Ghata, J.; Lewin, J. et Azérad, E.: Influence de Гabsorption de certaines graisses alimentaires sur les lipides et lipoprotéines du sang. - Einfluss eíníger Nahrungsfette auf Lípíde und Lípoproteíne des Blutes. - The Influence of the Absorption of Certain Dietary Fats on Blood Lipids and Lipoproteins

Sarles, H.; Badetti, J. et Greusard, C.: Etude de Faction des corps gras sur la contrac tion vésiculaire. I. Comparaison de Faction de divers corps gras. - Untersuchungen der Wirkung von Fettstoffen auf die Kontraktíon der Gallenblase. I. Vergleich der Wírkung verschíedener Fette. - A Study of the Action of Fatty Substances on the Contraction of the Gall bladder. I. Comparison of the Action of Different Fats 219

Sarles, H.; Dahl, C. et Badetti, J.: Etude de Faction des corps gras sur la contraction vé siculaire. II. Mise en evidence d'un phénomène hormonal inhibant la contraction vésicu laire. - Untersuchungen der Wírkung von Fettstoffen auf die Kontraktíon der Gallenblase. II. Nachweís eínes hormonalen Inhíbitorphänomens der Gallenblasenkontraktíon. - A Study 
of the Action of Fatty Substances on the Contraction of the Gallbladder. II. Evidence of a Hormonal Factor Inhibiting Contraction of the Gallbladder 223

Somogyi, J.C: Ernährungsphysiologische Aspekte der Sauermilchprodukte. - Nutritional Aspects of Soured and Fermented Milks. - Aspects nutritionnels des derives du lait ayant subi la fermentation lactique 39

Sprynarová, S.: vide Zbuzek, V.

StoSic, L.: Le rythme pathologique de la diurèse après surcharge d'eau chez les diabétiques. - Pathologíscher Diurese-Rhythmus nach Wasserbelastung beím Diabetiker. - The Patho logical Rhythm of Diuresis after Overloading with Water in the Diabetic 47 Vacula, J.: vide Zbuzek, V.

Vidal-Ribas, R.: Graisses d'alimentation et variations en composition chimique des lipides sanguins et de la graisse de depot. - Nahrungsfette und Veränderungen der Blut- und Depotfette. - Nutritional Fats and Variations in the Chemical Composition of Blood Lipids and of the Storage Fats

Vidal-Ribas, R.: Applications pratiques de regimes hypercaloriques équilibrés. - Praktisch $\beta$ Anwendung hyperkalorischer, ausgeglíchener Kostformen. - Practical Application of Balanced Hypercaloric Diets 27

Zbuzek, V.; BartoSová, D.; Vacula, J. et Sprynarová, S.: Evolution des taux plasmatiques des protêines, des acides gras, d'acide pyruvique, d'acide lactique au cours de Feffet physique suivant le degré d'entraînement. - Das Verhalten der Eíweíß-, Fcttsäuren-, Brenztraubensäure-, Milchsäure-Konzentratíon ím Plasma ivährend körperlícher Anstrengung bei verschiedenem Traíníngszustand. - Behaviour of the Plasma Concentrations of Protein, Fatty Acids, Pyruvic Acid and Lactic Acid during Physical Effort According to Different Training Conditions 246

Referate - Abstracts -Analyses 182

Buchbesprechungen - Book Reviews - Livres nouveaux $\quad 64,186$

Varia 64, 192

Mitteilungen der Redaktion - Editorial Note - Note éditoriale

65 